J. Clin. Chem. Clin. Biochem.

Vol. 18, 1980, pp. 595-601

\title{
Incomplete Hydrolysis of Cholesteryl Esters during the Enzymatic Cholesterol Determination as Evidenced by Aqueous Cholesteryl Ester Solutions: Comparison of Six Enzymatic Procedures with the Liebermann-Burchard Method
}

\author{
By R. M. Tel and G. T. Berends
}

Clinical Chemical Laboratory, St. Elisabeth's Hospital, Haarlem, The Netherlands

(Received October 8, 1979/March 6, 1980)

Summary: Aqueous solutions of cholesterol and some cholesteryl esters were prepared. The hydrolysis of cholesteryl esters with enzymatic methods could therefore be studied in some detail.

The total cholesterol concentration of the aqueous cholesterol and cholesteryl ester solutions was determined by 6 different enzymatic procedures as well as the Liebermann-Burchard method.

For some esters (acetate and arachidonate esters) the esterase reaction is not complete within the usual reaction time, whereas most other esters gave analytical re sults lower than the theoretical. With the Liebermann-Burchard method all esters reacted completely within the reaction time.

The esterases have very different specificities for the various cholesteryl esters.

With the enzymatic method several commercial control sera as well as human sera gave lower cholesterol concentrations than the Liebermann-Burchard method. These differences can be explained mainly by this incomplete hydrolysis.

Some practical recommendations are given.

Unvollständige Hydrolyse von Cholesterinestern bei der enzymätischen Cholesterinbestimmung in wäßrigen Lösungen von Cholesterinestern:

Vergleich von sechs enzymatischen Verfahren mit der Liebermann-Burchard-Methode

Zusammenfassung: Wäßrige Lösungen von Cholesterin und einigen Cholesterinestern wurden hergestellt; daran konnte die Hydrolyse von Cholesterinestern mit enzymatischen Methoden in einigen Einzelheiten untersucht werden.

Die Cholesterin-Gesamtkonzentration der wäßrigen Cholesterin- und Cholesterinester-Lösungen wurde mit sechs verschiedenen enzymatischen Verfahren sowie mit der Liebermann-Burchard-Methode bestimmt.

Für einige Esster (Acetat-, Arachidonat-) ist die Esterasereaktion innerhalb der üblichen Reaktionszeit nicht vollständig, während die meisten anderen Ester niedrigere Analysenresultate als theoretisch erwartet ergaben. Mit der LiebermannBurchard-Methode reagieren die Ester innerhalb der Reaktionszeit vollständig.

Die Esterasen haben sehr unterschiedliche Spezifitäten für die verschiedenen Cholesterinester.

Mit der enzymatischen Methode ergaben mehrere käufliche Kontrollseren als auch Serum vom Menschen niedrigere Cholesterinkonzentrationen als die Liebermann-Burchard-Methode. Diese Differenzen können im wesentlichen durch unvollständige Hydrolyse erklärt werden.

Einige praktische Hinweise werden gegeben.

\section{Introduction}

With the availability of the enzymes cholesterol esterase (EC 3.1.1.13) and cholesterol oxidase (EC 1.1.3.6), enzymatic methods for the determination of total serum cholesterol were developed for the clinical chemical laboratory $(1-3)$. The methods were assumed to be more specific (4-8) than the Liebermann-Burchard procedure $(4,5,9)$. Furthermore, the reaction conditions are considerably milder, as 
compared with the strong acidic medium of the Liebermann-Burchard method. Moreover, the enzymatic method can be used with various types of instrument $(7,8,10-12)$.

The cholesterol concentrations obtained with the enzymatic method are usually lower than those obtained by the Liebermann-Burchard method $(5,7,11,13)$. This was explained by the higher specificity of the enzymatic methods. Yet interferences of the enzymatic procedures by sterols $(6,14)$ and bilirubin $(15)$ have been described.

Recently it was demonstrated that the enzymatic reactions for the determination of cholesterol concentrations proceed via more complicated pathways than was previously expected $(11,13,16-19)$.

Very recently Haeckel (11) assumed that differences between the analytical values of cholesterol determinations from commercial control material might be a result of the various esterase sources.

The esterase step was not studied. In addition, Deacon (16) demonstrated different rates of hydrolysis of some cholesteryl esters (in alcoholic solution) in the cholesterol esterase catalyzed reaction.

For the Worthington and the Boehringer Mannheim reagent kits, $C h u$ found that longer times were required for comple te colour development with pure cholesteryl ester solutions in iso-propanol, than for the determination of cholesterol in human serum (17).

Very recently, during the National Meeting of the American Association for Clinical Chemistry, Cooper indicated that the enzymatic reactions are complex, being accompanied by the formation of a number of byproducts (13).

So far, the application of aqueous solutions of cholesteryl esters in the determination of total cholesterol has not been published, most probably due to the low solubility of cholesterol and cholesteryl esters in aqueous media.

In this paper, we describe the preparation of aqueous solutions of cholesterol and some cholesteryl esters. In all these solutions the total cholesterol concentrations were determined, using 6 different enzymatic methods and the Liebermann-Burchard method. The results were compared with the theoretical concentrations and gave us information about the rates of hydrolysis of the cholesteryl esters. All selected enzymatic methods have the cholesterol esterase and cholesterol oxidase catalyzed steps in common, but the subsequent indicator reactions are different. Furthermore, four of these methods have, as far as we know, not been described previously in the literature.

In addition, total cholesterol concentrations in some commercial control sera and human sera were determined. The results were compared, and could for the greater part be explained by the results of the experiments with the aqueous solutions of the cholesteryl esters.

\section{Materials and Methods}

\section{Reagents}

Cholesterol, cholesteryl oleate, and cholesteryl stearate were from BDH Chemicals Ltd., England.

Cholesteryl palmitate, cholesteryl arachidonate, cholestery linoleate, cholesteryl linolenate were from Sigma Chemical Company Ltd., England.

Cholesteryl acetate, sodium azide, acetic acid, sulfuric acid, acetic anhydride and sodium sulfate were from Merck AG., Germany.

Polyoxyethylene sorbitan monopalmitate (Tween-40) was from Sigma Chemical Company Ltd., England.

Nordihydroguaiaretic acid was from Fluka AG., Switzerland.

All reagents were purchased in the purest available state. Cholesterol and cholesteryl esters have a purity of $99 \%$ or higher.

Preparation of an aqueous solution of cholesterol (10.0 mmol/l)

This procedure was taken from Winckers \& Jacobs (20).

To $50 \mathrm{ml}$ of Tween- 40 in a $250 \mathrm{ml}$ flask was added $966.7 \mathrm{mg}$ of cholesterol and $25 \mathrm{mg}$ of nordihydroguaiaretic acid. The flask was heated in a boiling water bath until all the material was dissolved. Then about $150 \mathrm{ml}$ of a solution of sodium azide in water $(1 \mathrm{~g} / \mathrm{l})$ was added, and the mixture was heated to $100^{\circ} \mathrm{C}$ in a boiling water bath, until the solution was clear. The solution was slowly cooled to room temperature. The contents of the flask were then made up to $250 \mathrm{ml}$ with the sodium azide solution and thoroughly mixed; if necessary, the volume was adjusted again.

Nordihydroguaiaretic acid (antioxidant) and sodium azide were added to increase the shelf life of the cholesterol solution.

\section{Preparation of aqueous solutions of cholesteryl esters}

Aqueous solutions of cholesterol $(5.0 \mathrm{mmol} / \mathrm{l})$, cholesteryl acetate $(5.0 \mathrm{mmol} / \mathrm{l})$, cholesteryl stearate $(5.0 \mathrm{mmol} / \mathrm{l})$, cholesteryl palmitate $(5.0 \mathrm{mmol} / \mathrm{l})$, cholesteryl oleate $(4.4 \mathrm{mmol} / \mathrm{l})$, cholesteryl linoleate $(5.0 \mathrm{mmol} / \mathrm{l})$, cholesteryl linolenate $(5.0 \mathrm{mmol} / \mathrm{l})$ and cholesteryl arachidonate $(5.2 \mathrm{mmol} / \mathrm{l})$, were prepared according to the procedure as described above for cholesterol (10.0 $\mathrm{mmol} / \mathrm{l})$.

In the same manner a blank was prepared omitting cholesterol or cholesteryl esters.

All solutions are stable for at least two months at room temperature. At $+4^{\circ} \mathrm{C}-+8{ }^{\circ} \mathrm{C}$, precipitation of cholesterol and cholesteryl esters occurs.

\section{Control sera}

Autonorm (batcin 210), Autonorm (batch 217), Seronorm (batch 130 ), and Seronorm Lipid (batch 54 ) were from Nyegaard \& Co. Norway.

Precilip (lot 764) and Precinorm U (lot 717) were from Boehringer Mannheim, Germany.

Armtrol (batch 475) was from Ross Ltd., England. 
Hyland (lot NO4) from Travenol, Belgium.

Roche Lipid (lot S 2737) from Hoffmann-La Roche Ltd.2 Switzerland.

Wellcomtrol (lot K 1989) from Wellcome, England.

\section{Analytical methods}

For the enzymatic cholesterol determination the following commercially available kits were used:

1. Test-Combination Cholesterol, CHOD-PAP method (phenolaminophenazone-peroxidase chromogen) from Boehringer Mannheim. Germany

2. Cholesterol Test Roche, enzymatic (following the principle first described by Harders \& Helger, see 1.c. (21) from Hoffmann-La Roche \& Co. Ltd., Switzerland.

3. Dow Enzymatic Cholesterol Determination (phenol-aminoantipyrine-peroxidase chromogen) from Dow Chemical Co., USA.

4. System Cholesterol Enzymatic (following the principle first described by Harders \& Helger) from Merck AG., Germany.

5. Cholesterol Enzymatic (phenol-aminophenazone-peroxidase chromogen) from Technicon, USA.

6. Cholesterol Oxidase Reagent Kit (phenol-aminoantipyrineperoxidase chromogen) from Baker Diagnostics, USA.

Unless otherwise indicated we followed the manufacturer's instructions. The concentrations of the different components in the working solution of these enzymatic methods are listed in table 1.

For the Liebermann-Burchard procedure (22) we prepared the following four liters of reaction mixture: a mixture of $2400 \mathrm{ml}$ of acetic anhydride p.a. and $1200 \mathrm{ml}$ of acetic acid (glacial) p.a. was cooled to $-20^{\circ} \mathrm{C}$. To this mix ture was added carefully $400 \mathrm{ml}$ of cold $\left(-20^{\circ} \mathrm{C}\right)$ sulfuric acid p.a. The temperature rises to about $+25^{\circ} \mathrm{C}$. Finally, $80 \mathrm{~g}$ of sodium sulfate (anhydrous) p.a. was dissolved in the mixture.

\section{Instruments}

For the manual techniques we measured absorption on a Beckman spectrophotometer, model 26. The Technicon cholesterol enzymatic method was carried out on an Auto Analyzer II (Technicon).
The Roche enzymatic cholesterol test was carried out on a Centrifichem 300 (Union Carbide). The Liebermann-Burchard procedure was carried out on an Auto Analyzer II at a constant temperature of $56^{\circ} \mathrm{C}$ (40 samples per hour, the samples were prediluted $1: 2$ with $9 \mathrm{~g} / 1 \mathrm{NaCl}$-solution).

\section{Standardization and performance}

The prepared aqueous solution of cholesterol $(10.0 \mathrm{mmol} / \mathrm{l})$ was used as the standard for all methods. An aqueous solution of cholesterol $(5.0 \mathrm{mmol} / \mathrm{l})$ was always taken as a control material for all methods. The manual determinations were performed in quadruplicate, whereas the experiments on the Centrifichem and Auto Analyzer II were carried out in triplicate. All methods give reproducible concentrations within $0.1 \mathrm{mmol} / \mathrm{l}$.

\section{Results}

Linearity between absorbance and concentration of all the kits was tested by using dilutions of the aqueous cholesterol solution $(10.0 \mathrm{mmol} / \mathrm{l})$. In the range of 0.0-10.0 mmol/1, all methods showed a linear relationship between absorbance and concentration. However. calibration curves of the Boehringer and Roche methods demonstrated a small negative $y$-intercept. In these cases the cholesterol concentrations were determined with the use of calibration curves. Since the Merck test advices only $10 \mu \mathrm{l}$ of sample we preferred to use a Hamilton diluter for better precision of the results. We recommend adjustment of the temperature of reagents to that of the reaction, before they are dispensed. The total cholesterol concentrations of aqueous solutions of cholesteryl esters as determined by the different methods are shown in table 2 .

The enzymatic methods give lower cholesteryl ester concentrations than does the Liebermann-Burchard

Tab. 1. Contents of the working solution of the different enzymatic cholesterol kits.

\begin{tabular}{|c|c|c|c|c|c|c|c|}
\hline Constituents & & $\begin{array}{l}\text { Method } \\
\text { Merck }\end{array}$ & Roche & $\begin{array}{l}\text { Boeh- } \\
\text { ringer }\end{array}$ & Baker & Dow & Technicon \\
\hline $\begin{array}{l}\text { Potassium phosphate } \\
\text { pH } \\
\text { Phenol } \\
\text { 4-Aminophenazone } \\
\text { Potassium iodide } \\
\text { Ammonium molybdate } \\
\text { Alkylbenzyldimethylammonium- } \\
\text { chloride } \\
\text { Triton X-100 } \\
\text { Cholesterol esterase } \\
\text { Cholesterol oxidase } \\
\text { Peroxidase } \\
\text { Sodium cholate } \\
\text { Sodium azide } \\
\text { Methanol } \\
\text { Hydroxypolyethoxydodecane } \\
\text { Polyethyleneglycolmono[p-(1,1,3,3,- } \\
\text { tetramethylbutyl.)phenyl]ether } \\
\text { Pegospcrse }\end{array}$ & $\begin{array}{l}(\mathrm{mol} / \mathrm{l}) \\
(\mathrm{mmol} / \mathrm{l}) \\
(\mathrm{mmol} / 1) \\
(\mathrm{mol} / \mathrm{l}) \\
(\mu \mathrm{mol} / 1) \\
(\mathrm{g} / 1) \\
(\mathrm{g} / 1) \\
(\mathrm{U} / 1) \\
(\mathrm{U} / 1) \\
(\mathrm{U} / 1) \\
(\mathrm{mmol} / 1) \\
(\mathrm{mmol} / 1) \\
(\mathrm{mmol} / 1) \\
(\%) \\
(\mathrm{g} / \mathrm{l}) \\
(\mathrm{ml} / \mathrm{l})\end{array}$ & $\begin{array}{c}0.2 \\
6.2 \\
\\
0.12 \\
10 \\
0.1\end{array}$ & $\begin{array}{c}0.2 \\
6.2 \\
\\
0.12 \\
10 \\
0.1 \\
2 \\
48 \\
36\end{array}$ & $\begin{array}{c}0.4 \\
7.7 \\
10 \\
1\end{array}$ & $\begin{array}{r}85 \\
165 \\
17200 \\
3\end{array}$ & $\begin{array}{r}66 \\
120 \\
46000 \\
10\end{array}$ & $\begin{array}{r}93 \\
131 \\
1547\end{array}$ \\
\hline
\end{tabular}


Tab. 2. Analytical results (in $\mathrm{mmol} / \mathrm{l}$ ) of the cholesterol determination in aqueous solutions of cholesterol and some cholesteryl esters (Standard solution: cholesterol $10.0 \mathrm{mmol} / \mathrm{l}$ ).

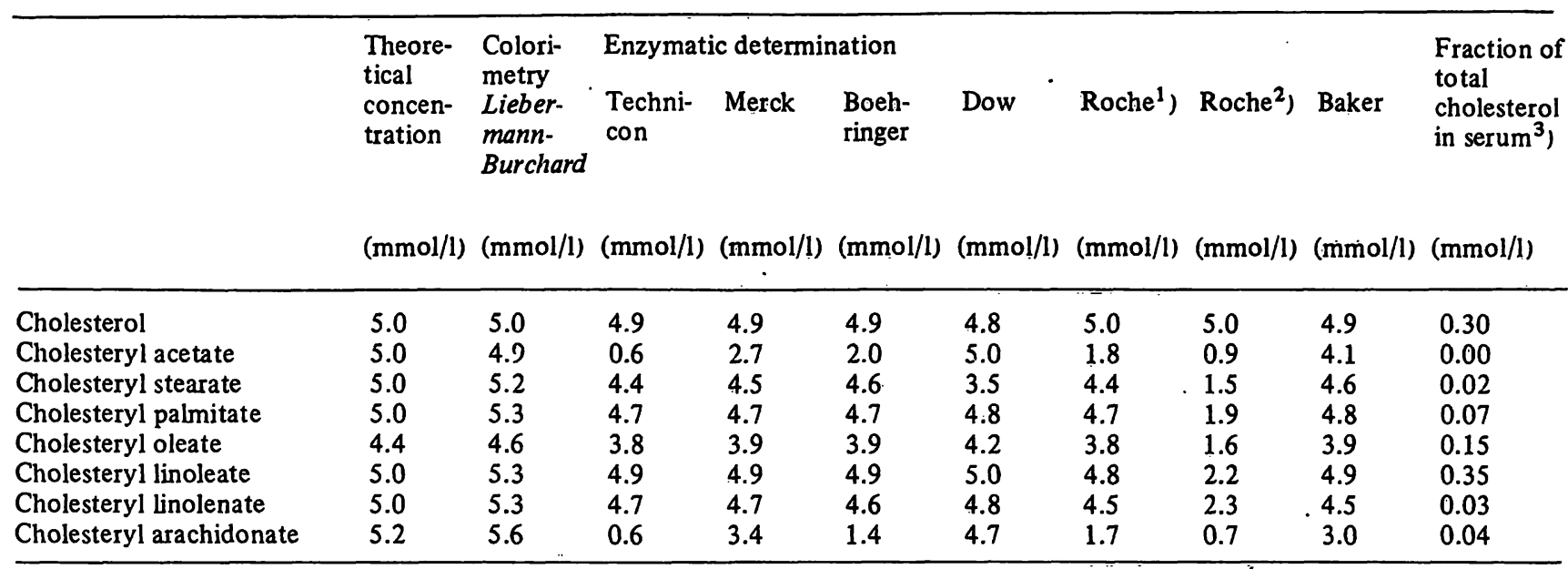

1) Centrifichem, $24 \mathrm{~min}$ at $30^{\circ} \mathrm{C}$.

2) Centrifichem, $14 \mathrm{~min}$ at $25^{\circ} \mathrm{C}$.

3) See 1.c. $(16,23-25)$.

procedure. The most significant result is that the enzymatic methods gave even lower cholesterol concentrations than might be expected from the weighed quantities. Especially low concentrations were measured with the acetate and arachidonate esters. Only with the Dow method, does the hydrolysis of the acetate and arachidonate esters seem to be nearly complete, but in this case the hydrolysis of the stearate ester was incomplete.

It seems unlikely that Tween- 40 may interfere with the esterase reaction, because all enzymatic methods show that hydrolysis of the linoleate ester is complete. Additional support is obtained from the Dow Chemical method, which, in contrast to the other methods, gives complete hydrolysis of the acetate ester. Moreover, hydrolysis of the other esters, with the exception of cholesteryl stearate, is nearly complete within the reaction time.

Since the Roche test gave a Centrifichem procedure, it was easy to measure the increase of the absorbance with increasing reaction time for both the aqueous cholesterol and the cholesteryl ester solutions. First the manufacturer's instructions were carried out (14 $\mathrm{min}$ at $25^{\circ} \mathrm{C}$ ). The results are shown in table 2 . The hydrolysis is not complete, but the reaction with free cholesterol is still not ended. Figure 1 shows that even at $30^{\circ} \mathrm{C}$ none of the reactions is complete within 14 minutes.

Only the curves of free cholesterol solutions and those of the acetate, arachidonate, oleate and linoleate esters were drawn. The curves of the other esters are found between those of the linoleate and oleate esters. The final absorbance of the free cholesterol solution (5.0 $\mathrm{mmol} / \mathrm{l}$ ) is less than half the absorbance of the free cholesterol solution $(10.0 \mathrm{mmol} / \mathrm{l})$. This may suggest a

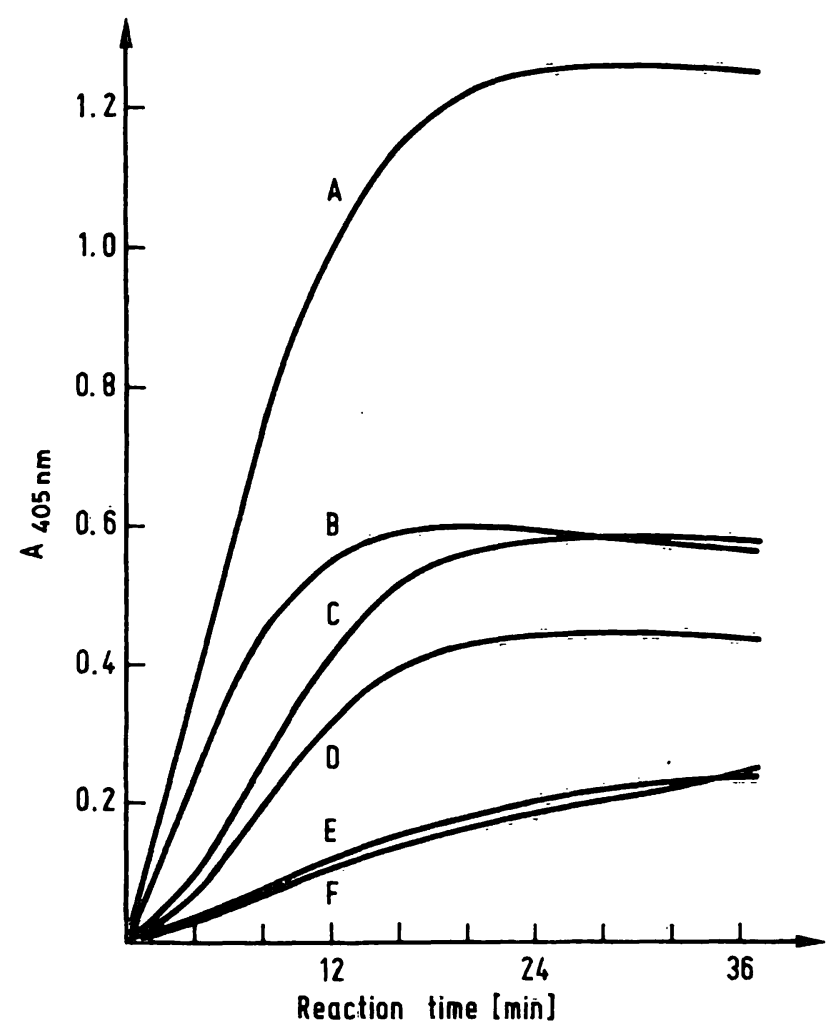

Fig. 1. Variation of absorbance with time during the reaction of cholesterol and some cholesteryl esters with the Roche kit.

A: Cholesterol $(10.0 \mathrm{mmol} / \mathrm{l})$.

B: Cholesterol $(5.0 \mathrm{mmol} / \mathrm{l})$ :

C: Cholesteryl linoleate $(5.0 \mathrm{mmol} / \mathrm{l})$.

D: Cholesteryl oleate $(4.4 \mathrm{mmol} / \mathrm{l})$.

E: Cholesteryl acetate $(5.0 \mathrm{mmol} / \mathrm{l})$.

F: Cholesteryl arachidonate $(5.2 \mathrm{mmol} / \mathrm{l})$.

nonnlinear assay even for free cholesterol, but it results from a small negative $y$-intercept of the calibration curve. This figure clearly shows that the initial reaction rate of the free cholesterol solution $(5.0 \mathrm{mmol} / \mathrm{l})$ is greater 
Tab. 3. Concentrations of total cholesterol (mmol/1) in several control sera (Standard solution: cholesterol $10.0 \mathrm{mmol} / \mathrm{l}$ ).

\begin{tabular}{|c|c|c|c|c|c|c|c|}
\hline & \multirow{2}{*}{$\begin{array}{l}\text { Colori- } \\
\text { metry } \\
\text { Lieber- } \\
\text { mann- } \\
\text { Burchard } \\
\text { (mmol/1) }\end{array}$} & \multicolumn{6}{|c|}{ Enzymatic determination } \\
\hline & & $\begin{array}{l}\text { Techni- } \\
\text { con } \\
(\mathrm{mmol} / \mathrm{l})\end{array}$ & $\begin{array}{l}\text { Merck } \\
(\mathrm{mmol} / \mathrm{l})\end{array}$ & $\begin{array}{l}\text { Boeh- } \\
\text { ringer } \\
\text { (mmol/1) }\end{array}$ & $\begin{array}{l}\text { Dow } \\
\text { Chemical } \\
(\mathrm{mmol} / \mathrm{l})\end{array}$ & $\begin{array}{l}\left.\text { Roche }^{1}\right) \\
(\mathrm{mmol} / \mathrm{l})\end{array}$ & $\begin{array}{l}\text { Baker } \\
\text { (mmol/l) }\end{array}$ \\
\hline $\begin{array}{l}\text { Cholesterol }(5 \mathrm{mmol} / 1) \\
\text { Autonorm } 210 \\
\text { Autonorm } 217 \\
\text { Armtrol } 475 \\
\text { Hyland } \\
\text { Precilip } \\
\text { Precinorm U } \\
\text { Roche Lipid } \\
\text { Seronorm 130 } \\
\text { Seronorm Lipid } \\
\text { Wellcomtrol }\end{array}$ & $\begin{array}{l}5.0 \\
3.8 \\
6.2 \\
4.4 \\
3.6 \\
4.3 \\
3.9 \\
9.3 \\
2.7 \\
7.1 \\
4.9\end{array}$ & $\begin{array}{l}4.9 \\
3.2 \\
5.0 \\
3.8 \\
3.1 \\
3.6 \\
3.3 \\
7.8 \\
2.4 \\
6.3 \\
3.4\end{array}$ & $\begin{array}{l}4.9 \\
2.8 \\
4.7 \\
3.3 \\
2.9 \\
3.4 \\
3.2 \\
7.3 \\
1.8 \\
6.0 \\
3.5\end{array}$ & $\begin{array}{l}4.9 \\
3.9 \\
5.7 \\
4.5 \\
3.7 \\
4.3 \\
4.1 \\
8.7 \\
2.9 \\
7.2 \\
4.3\end{array}$ & $\begin{array}{l}4.8 \\
3.6 \\
5.8 \\
- \\
3.2 \\
3.8 \\
3.6 \\
9.4 \\
2.3 \\
7.2 \\
4.6\end{array}$ & $\begin{array}{l}5.0 \\
2.7 \\
4.4 \\
- \\
2.8 \\
3.2 \\
3.1 \\
7.2 \\
1.9 \\
5.8 \\
3.3\end{array}$ & $\begin{array}{l}4.9 \\
3.7 \\
5.7 \\
- \\
3.4 \\
4.0 \\
3.7 \\
8.2 \\
2.7 \\
7.0 \\
4.3\end{array}$ \\
\hline
\end{tabular}

1) Centrifichem, $24 \mathrm{~min}$ at $30^{\circ} \mathrm{C}$.

than those of the cholesteryl esters. Moreover, the oleate, acetate, and arachidonate esters have remarkably lower absorbances than were expected from the theoretical total cholesterol concentrations. Even after $36 \mathrm{~min}$ at $30^{\circ} \mathrm{C}$ the hydrolysis of cholesteryl arachidonate is not complete.

Furthermore, with long reaction times the absorbance of the reaction mixture decreased. On account of the above findings an incubation time of $24 \mathrm{~min}$ at $30^{\circ} \mathrm{C}$ was chosen. The results are given in table 2 . Similar results were found with an incubation time of $16 \mathrm{~min}$ at $37^{\circ} \mathrm{C}$.

Determination of total cholesterol concentration in a number of commercial control sera was performed with all methods mentioned. In order to cancel out some variables, the experiments with the control sera were carried out on the same day. Moreover, for all the methods of cholesterol determination, the same vial of a particular control serum was used. The results are given in table 3. From table 3, it can be seen that the tests of Baker and Boehringer give equal or somewhat lower concentrations than the Liebermann-Burchard technique. The tests of Technicon, Merck, and Roche show considerably lower values than those obtained with the Liebermann-Burchard procedure. The Merck and Roche methods on their turn, give somewhat lower results than the Technicon method.

We emphasize that the colour development of the chromogen systems is faster in the control sera (and in human sera) than in the case of the aqueous solutions of cholesterol. As already mentioned the colour development in the Roche test for free cholesterol is complete after $24 \mathrm{~min}$ at $30^{\circ} \mathrm{C}$. For the control sera, the colour development is already complete after $14 \mathrm{~min}$ at $25^{\circ} \mathrm{C}$, and is thus within the manufacturer's reaction time.
In addition, cholesterol concentrations were determined in a number of patient sera (tab. 4). Some of these sera were expected to contain rather high cholesterol levels. The values obtained with most enzymatic methods are lower than those observed with the Liebermann-Burchard method. The Baker and Boehringer tests gave nearly the same results as the Liebermann-Burchard method.

The Dow test gave somewhat lower results than the Liebermann-Burchard method, but still higher than those obtained by the Merck, Technicon and Roche tests.

Tab. 4. Cholesterol concentrations ( $\mathrm{mmol} / \mathrm{l})$ in a number of patient sera (Standard solution: cholesterol $10.0 \mathrm{mmol} / \mathrm{l}$ ).

\begin{tabular}{|c|c|c|c|c|}
\hline \multirow[b]{2}{*}{ Patient } & \multirow{2}{*}{$\begin{array}{l}\text { Colori- } \\
\text { metry } \\
\text { Lieber- } \\
\text { mann- } \\
\text { Burchard } \\
\text { (mmol/l) }\end{array}$} & \multicolumn{3}{|c|}{ Enzymatic determination } \\
\hline & & $\begin{array}{l}\text { Boeh- } \\
\text { ringer } \\
(\mathrm{mmol} / \mathrm{l})\end{array}$ & $\begin{array}{l}\text { Techni- } \\
\text { con } \\
(\mathrm{mmol} / \mathrm{l})\end{array}$ & $\begin{array}{l}\text { Merck } \\
(\mathrm{mmol} / \mathrm{l})\end{array}$ \\
\hline $\begin{array}{r}1 \\
2 \\
3 \\
4 \\
5 \\
6 \\
7 \\
8 \\
9 \\
10\end{array}$ & $\begin{array}{l}8.0 \\
6.6 \\
4.8 \\
7.5 \\
6.2 \\
7.5 \\
5.6 \\
7.0 \\
6.4 \\
9.0\end{array}$ & $\begin{array}{l}7.9 \\
6.4 \\
4.9 \\
7.5 \\
6.1 \\
7.4 \\
5.8 \\
7.0 \\
6.5 \\
9.0\end{array}$ & $\begin{array}{l}7.3 \\
5.9 \\
4.4 \\
7.0 \\
5.7 \\
7.0 \\
5.3 \\
6.5 \\
5.9 \\
8.4\end{array}$ & $\begin{array}{l}7.1 \\
5.7 \\
4.0 \\
6.9 \\
5.5 \\
6.8 \\
5.2 \\
6.4 \\
6.0 \\
8.5\end{array}$ \\
\hline & & $\begin{array}{l}\text { Dow } \\
\text { (mmol/l) }\end{array}$ & $\begin{array}{l}\text { Baker } \\
(\mathrm{mmol} / \mathrm{l})\end{array}$ & $\begin{array}{l}\text { Roche } \\
(\mathrm{mmol} / \mathrm{l})\end{array}$ \\
\hline $\begin{array}{l}11 \\
12 \\
13 \\
14 \\
15 \\
16 \\
17\end{array}$ & $\begin{array}{l}5.5 \\
7.8 \\
7.3 \\
6.8 \\
6.7 \\
6.2 \\
6.0\end{array}$ & $\begin{array}{l}5.0 \\
7.6 \\
6.9 \\
6.4 \\
6.4 \\
5.9 \\
5.4\end{array}$ & $\begin{array}{l}5.3 \\
7.8 \\
7.3 \\
6.8 \\
6.5 \\
6.2 \\
5.8\end{array}$ & $\begin{array}{l}4.4 \\
7.4 \\
6.6 \\
6.0 \\
6.0 \\
5.6 \\
5.1\end{array}$ \\
\hline
\end{tabular}


The last column of table 2 shows the normal distribution of cholesterol and cholesteryl esters in serum. A mixture of cholesterol and cholesteryl esters of $7.0 \mathrm{mmol} / \mathrm{l}$ was made containing the same distribution.

All the methods were used to determine the total cholesterol concentration in this mixture. The results are shown in table $5 \mathrm{a}$. In the second column we show the recovery of the analytical value with respect to the theoretical concentration.

A theoretical recovery can also be calculated from the normal distribution of cholesterol and cholesteryl esters and the results from table 2. For each separate ester the recovery of the analytical concentration with respect to the weighed value can be determined from table 2 . This recovery has been multiplied by the relative content of that particular ester in a normal serum. This result gives the contribution of the recovery of that ester to the total recovery. The theoretical recovery is equal to the sum of these contributions. The values are shown in the third column of table $5 \mathrm{a}$. It can be seen that the analytical recovery is in excellent agreement

Tab. 5. Determination and recovery of the total cholesterol concentration in an aqueous solution of a natural mixture of cholesterol and cholesteryl esters, and correction for incomplete hydrolysis of the cholesteryl esters.

a) Determination and recovery of the total cholesterol concentration in an aqueous solution of a mixture of cholesterol and cholesteryl esters corresponding to a normal distribution in native sera.

(Total cholesterol concentration is $7.0 \mathrm{mmol} / \mathrm{l}$ ).

\begin{tabular}{llll}
\hline Method & $\begin{array}{l}\text { Analytical } \\
\text { concentra- } \\
\text { tion } \\
\text { (mmol/l) }\end{array}$ & $\begin{array}{l}\text { Analytical } \\
\text { recovery }\end{array}$ & $\begin{array}{l}\text { Theoretical } \\
\text { recovery }\end{array}$ \\
\hline Liebermann-Burchard & 7.2 & 103 & $(\%)$ \\
Technicon (enzymatic) & 6.4 & 91 & 103.8 \\
Merck & 6.6 & 94 & 92.8 \\
Boehringer & 6.5 & 93 & 93.0 \\
Dow Chemical & 6.8 & 97 & 97.9 \\
Roche & 6.5 & 93 & 92.9 \\
Baker & 6.7 & 96 & 95.2
\end{tabular}

b) Determination of the total cholesterol concentration in a native serum corrected to obtain $100 \%$ recovery.

\begin{tabular}{llll}
\hline Method & $\begin{array}{l}\text { Analytical } \\
\text { concentra- } \\
\text { tion }\end{array}$ & $\begin{array}{l}\text { Corrected } \\
\text { concentra- } \\
\text { tion from } \\
\text { analytical } \\
\text { recovery } \\
\text { (mmol/1) }\end{array}$ & $\begin{array}{l}\text { Corrected } \\
\text { concentra- } \\
\text { tion from } \\
\text { theoretical } \\
\text { recovery } \\
\text { (mmol/1) }\end{array}$ \\
\hline Liebermann-Burchard & 7.2 & 7.0 & 7.0 \\
Technicon (enzymatic) & 6.5 & 7.1 & 7.0 \\
Merck & 6.8 & 7.2 & 7.1 \\
Boehringer & 7.2 & 7.7 & 7.7 \\
Dow Chemical & 6.9 & 7.1 & 7.0 \\
Roche & 6.6 & 7.1 & 7.1 \\
Baker & 7.1 & 7.4 & 7.4 \\
\hline
\end{tabular}

with the theoretical one. For all these methods we applied a correction of the cholesterol concentrations found in human serum (tab. $5 \mathrm{~b}$ ) by multiplication of the analytical cholesterol concentrations by 100 , divided by the recovery (in \%).

The example in table $5 \mathrm{~b}$ indicates that, with the exception of Boehringer's method, comparable results are obtained. The other human sera behave in the same manner.

Bilirubin concentrations were also determined, but no correction of cholesterol concentrations was necessary.

\section{Discussion}

By preparing aqueous solutions of cholesterol and cholesteryl esters, it was possible to obtain information about the hydrolysis of the esters in the esterase step.

Table 2 shows that with the enzymatic methods relatively low total cholesterol concentrations were obtained for the ester solutions. However, for all methods the cholesterol concentration for the free cholesterol solution $(5.0 \mathrm{mmol} / \mathrm{l})$ is equal to the theoretical one. It indicates that the reaction with cholesterol oxidase is complete within the reaction time. Therefore we assume that the differences between the analytical values of the various cholesteryl esters are a result of different rates of hydrolysis of the cholesterol esterase step. This conclusion is in agreement with recent results of Deacon $\&$ Dawson (16), but in our case the relative rates of the enzymatic hydrolysis of the esters vary strongly with those found by these authors. Those differences may be a result of the great differences in the reaction media. Deacon \& Dawson used propan-2-ol as the solvent, whereas we dissolved the esters in an aqueous medium.

Since the relatively low concentrations can be explained by the degree of hydrolysis in the esterase step, the assumed specificity of the enzymatic methods becomes more or less doubtful. The commercial control sera (see tab. 3) exhibit additional effects, because considerably larger differences in cholesterol concentrations were obtained between the enzymatic methods and the Liebermann-Burchard procedure, than might be expected from the results from table 2 . An explanation could be that some control sera might contain relatively high concentrations of cholesteryl ace tate and/or cholesteryl arachidonate, but in our opinion a more probable explanation is that in the commercial sera, the esterase step of some kits is partly inhibited (especially the Technicon, Merck, and Roche tests).

The Dow and Baker tests indicated higher cholesterol concentrations in the control sera than were found by the kits of Merck, Technicon and Roche. Most probably this is a result of better hydrolysis at the esterase 
step (see tab. 2). However, the Boehringer kit gave higher values than were expected from the results in table 2. The reactions of control sera and of free cholesterol with the Boehringer kit showed no further increase in absorbance after longer reaction times. Unfortunately these experiments gave no satisfactory explanation for the relatively high analytical values of the Boehringer kit.

The differences between the total cholesterol concentrations in 27 human sera, as determined by all methods, are smaller than were obtained with the commercial control sera (see tab. 4). This is most probably a result of the above mentioned additional effects which occur in commercial sera.

In table 2 we also gave the mean distribution of cholesterol and some of its esters in a normal serum. These values were taken from the mean of the distributions as described in 1.c. $(16,23-25)$.
The differences between the analytical values of the enzymatic methods and the Liebermann-Burchard method can for the greater part be explained (see Results).

Theoretically the enzymatic cholesterol determination should have higher specificity than the "chemical" Liebermann-Burchard method. Practically, however, as demonstrated in this paper, the enzymatic methods are more complicated than previously was expected because of the different concentrations of cholesteryl esters in native sera.

If commercial sera are used for standardization, large differences in the cholesterol concentrations may be expected for the various enzymatic methods. These differences can be reduced considerably if aqueous solutions of cholesterol are used.

\section{References}

1. Hernandez, H. H. \& Chaikoff, I. L. (1957), J. Biol. Chem. $228,447-457$.

2. Hyun, J., Kothari, H., Herm, E:, Mortenson, J., Treadwell, C. R., \& Vahouny, G. V. (1969), J. Biol. Chem. 244, 1937-1945.

3. Röschlau, P., Bernt, E. \& Gruber, W. (1974), J. Clin. Chem. Clin. Biochem. 12, 226.

4. Zak, B. (1977), Clin. Chem. 23, 1201-1214.

5. Hindriks, F. R., Wolthers, B. G. \& Groen, A. (1977), Clin. Chim. Acta 74, 207-215.

6. Allain, C. C., Poon, L. S., Chan, C. S. G., Richmond, W. \& Fu, P. C. (1974), Clin. Chem. 20, 470-475.

7. Gadsden, R. H., Phelps, C. A. \& Crews, R. M. (1976), Clin. Chem. 22, 1179.

8. Klose, S., Schlumberger, H. \& Drobeck, K. (1978), Clin. Chem. 24, 1425.

9. Röschlau, P., Bernt, E. \& Gruber, W. (1974), J. Clin. Chem. Clin. Biochem. 12, 403.

10. Nobbs, B. T., Smith, J. M. \& Walker, A. W. (1977), Clin. Chim. Acta 79, 391-397.

11. Haeckel, R., Sonntag, O., Külpmann, W. R. \& Feldmann, U. (1979), J. Clin. Chem. Clin. Biochem. 17, 553-563.

12. Hunter, L. L. \& Grady, H. J. (1977), Clin. Chem. 23, 1945-1947.

13. Cooper, G. R., Ullman, M. D., Hażlehurst, J., Miller, D. T. \& Bayse, D. D. (1979), Clin. Chem. 25, 1074.
14. Munster, D. J., Lever, M. \& Carrell, R. W. (1976), Clin. Chim. Acta 68, 167-175.

15. Pesce, M. A. \& Bedourian, S. H. (1977), Clin Chem. 23, 757-760.

16. Deacon, A. C. \& Dawson, P. J. G. (1979), Clin. Chem. 25, 976-984.

17. Chu, S. Y. \& Turkington, V. E. (1978), Clin. Biochem. 11, 70-72.

18. De Hoff, J. L., Davidson, L. M. \& Kritchevsky, D. (1978), Clin. Chem. 24, 433-435.

19. Borner, K. \& Klose, S. (1977), J. Clin. Chem. Clin. Biochem. $15,121-130$.

20. Winckers, P. L. M. \& Jacobs, P., Eudokia Hospital, Rotterdam, The Netherlands.

21. Harders, H. D. \& Helger, R. J. (1977), J. Clin. Chem. Clin. Biochem. 15, 159.

22. Huang, T. C., Chen, C. P., Wefler, V. \& Raftery, A. (1961), Anal. Chem. 33, 1404-1407.

23. Personal communication, Gaubius Institute for Lipid Research, Leiden, The Netherlands.

24. Mills, G. L., Taylaur, C. E. \& Wilkinson, P. A. (1967), Clin. Chim. Acta 15, 263-267.

25. Beukers, H., Veltḳamp, W. A. \& Hooghwinkel, G. J. M. (1969), Clin. Chim. Acta 25, 403-408.

Drs. G. T. Berends Clinical Chemical Laboratory St. Elisabeth's Hospital Boerhaavelaan 22 2035 RC Haarlem The Netherlands 


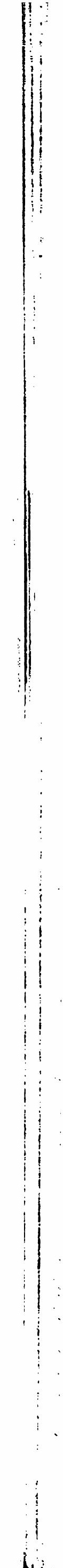

